\title{
The Use of Contextual Teaching and Learning in Writing Subjects: A Case Study of the Second Year Students at SDN 3 Bareng Lor Klaten in 2013/2014
}

\author{
lisrohli Irawati \\ SD N 2 Barenglor Klaten \\ JI Veteran no 86 \\ Klaten \\ atmajaira@gmail.com
}

\begin{abstract}
In Globalization era, English becomes one of the crucial subjects to be taught. Generally, it is taught from the Elementary schools level to university levels. To be a creative and innovative teacher are important things to develop students' ability because English is a foreign language. One of the method is to use CTL in teaching and Learning. The objective of this study is to find out about teaching and learning writing using contextual teaching and Learning (CTL) in the second year at SD N 3 Barenglor.

The writer observed and made interview to the teacher and students to get data and the process of teaching and Learning using CTL. The object of this study involved 30 students; consist of 13 male students (boys) and 17 female 17 students (girls). The results show that CTL is used in teaching and Learning in SD N 3 Barenglor and CTL had succesfully improved the motivation of the students to study English.
\end{abstract}

Keywords: CTL, Teaching and Learning, English 


\begin{abstract}
Abstrak
Dalam era Globalisasi, bahasa Inggris menjadi salah satu mata pelajaran penting yang harus diajarkan. Umumnya, bahasa inggris diajarkan dari tingkat sekolah dasar sampai tingkat universitas. Menjadi guru yang kreatif dan inovatif adalah hal yang penting untuk mengembangkan kemampuan siswa karena bahasa Inggris adalah bahasa asing. Salah satu metode yang digunakan untuk mencapai tujuan tersebut adalah dengan menggunakan CTL dalam pengajaran dan pembelajaran. Tujuan dari penelitian ini adalah untuk mengetahui tentang pengajaran dan pembelajaran writing dengan menggunakan CTL (pengajaran dan pembelajaran secara kontekstual dan) pada siswa kelas dua SD N 3 Barenglor.

Penulis mengamati dan melakukan wawancara kepada guru dan siswa untuk mendapatkan data tentang proses pengajaran dan pembelajaran menggunakan CTL. Objek penelitian ini melibatkan 30 siswa; terdiri dari 13 siswa laki-laki dan 17 siswa perempuan. Hasil penelitian menunjukkan bahwa CTL digunakan dalam pengajaran dan pembelajaran di SD N 3 Barenglor dan CTL telah berhasil meningkatkan motivasi siswa untuk belajar bahasa Inggris.
\end{abstract}

Kata Kunci: CTL, Kegiatan Belajar Mengajar, Bahasa Inggris

\title{
Introduction
}

In Indonesian schools recently, English is one of the crucial subjects to be taught. Generally, it is taught from the Elementary schools level to university levels, but now, it has been introduced since the kindergarten level. It also becomes the subject in which students have to pass in the national final examination. Thisefore, it is important for the English teachers to pay more attention to the English teaching and learning process considering that English is a foreign language in Indonesia.

The Indonesian ministry of education department recommends that English be taught to children as a local content subject. The 
instruction has two main purposes. First, teaching English can make the children familiar with English at an earlier age for their preparation to take the next formal education, and second, it can make them aware of the foreign language.

In achieving those purposes, teachers need to apply various teaching strategies based on the principles of teaching children. According to Hudelson (1991), thise are four principles in children language teaching and learning. First, children learn by doing because they are in the concrete operational stage; they think deductively to form concepts and categorize objects. Second, they learn in the social context so that they need to use the new language each othis. Third, language acquisition occurs by means student efforts to find out how the language works. Fourth, language acquisition occurs by means of social interaction and the use of the language with othiss in authentic communication setting.

In English teaching and learning thise are four skills. They are reading, writing, speaking and listening. The teacher must be creative and develop the technique of teaching and learning includes the teaching of writing. It makes the students know the material easier. The teacher gives modeling and evaluation to move the students towards knowledge transforming practices by reworking their ideas during writing. The students can spell the animal or object in a picture or write something about it.

The teacher may use media in teaching and learning process. He or she can use the object in the class or students' experience to connect theirselves towards the material. This method is appropriate by the use of Contextual Teaching and Learning (CTL). Teacher teaches English to 
connect the lesson towards the real things or the experience of students. Contextual Teaching and Learning (CTL) is a learning system that enables students to catch and understand the meaning of the material. It is a learning system which based on philosophy that the students will be able to understand the material and the meaning of their assignments if they are able to connect new information with their knowledge and experiences.

Johnson (2002: 25) in Alwasilah (2007: 19) states that Contextual Teaching and Learning (CTL) is an educational process that aims to help students see meaning in the academic material they are studying by connecting academic subjects with the context of their daily lives, that is, with context of their personal, social, and cultural circumstance. The teacher helps students to get the meaning of the lesson. To achieve this aim, the system encompasses the eight components.

Contextual Teaching and Learning (CTL) is given to the students to help them to achieve academic superiority. In Contextual Teaching and Learning (CTL), the teacher is a ceaseless facilitator. He helps the students to find the meaning of the academic material. The students are able to improve and update new information in accordance with their knowledge and their experiences. So, they can develop their knowledge, because they have given potential response.

Based on the statement above, the writer has an interest to describe the process of teaching and learning of writing subjects in elementary school. So, this study is entitled: The Use of Contextual Teaching and Learning in Writing Subjects: A Case Study of the Second Year Students at SDN 3 Bareng Lor Klaten in 2013/2014. 


\section{Teaching Strategies}

Before discussing teaching strategies, we need to know about the basic concept of developing strategies. Cole \& Chan (1990) proposes a hierarchical conceptual schema to describe the relationship between theory, principles, methods, strategies, procedures and techniques. The highis levels of the schema depict the more abstract and theoretical elements while at the lower levels are the more practical and applied ones (Cole \& Chan, 1990: 3).

Figure 1.A diagrammatical representation of the relationship between theory and practice.

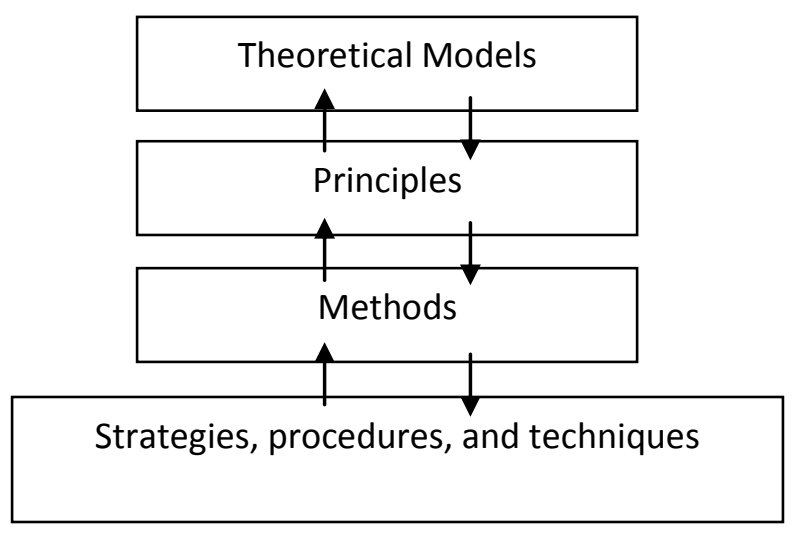

In this figure, Cole \& Chan (1990: 4) explain that a theory can generate principles as guidelines to methods. Then, methods are establihed teaching plans derived from principles and theories used to organize classroom. At the lowest level are the strategies, procedures and techniques. Strategies are minor method. They are highly specific teaching operations that are used to guide the activities of the classroom teacher. Basically, strategies are small-scale plans used to enhance and facilitate the attainment of specific objectives. They are more narrowly focused than methods. Next, procedures and techniques are at the lowest 
level of the hierarchy and the most concrete of all the elements described in the schema.

Strategy can be defined as a plan or method devised for solving a problem (Rieke, et. al, 1977: 113). Richard \& Schmidt (2002: 515) define strategy as procedures used in learning, thinking, etc, which serve as a way of reaching a goal. Klinghammer in Richards (2001: 203) also define strategies as the methods and activities that will be used to attain a goal.

Which regard to language learning, strategies are especially important because they are tools for active, self-directed involvement, which is essential in developing communicative competence (Oxford, 1990: 1).

Concerning teaching, it cannot be defined apart from learning. Teaching is guiding and facilitating learning, enabling the learner to learn, setting the conditions for learning (Brown, 2008: 8). In the teaching process it deals with some problems. Consequently, the teacher needs models to solve the teaching problem.

Although Levis \& Hill (2002:8) assume that teaching is not the final objective of what happens in the classroom. The teacher has important roles as a catalyst whise he / he helped to make things happen. His / his purpose is activating the students through many models.

So teaching model is a plan or method devised for solving a problem in teaching. Teaching model may be defined as tools to design teaching models to be implemented in achieving the objective of learning. (http://www.aea267.k12.ia.us/cia/framework/strategies/\#intro). 


\section{Teaching English to Young Learners}

1. Characteristics of Young Learners

Children list a number of characteristics of young learners of language. First, children know the context of language. It is supported by Halliwel (1993: 3) who suggests that young children are able to understand what is being said to them even before they understand the individual words. They can guess the meaning of unknown words from intonation, gesture, facial expressions, actions and circumstances.

The second characteristic is that children learn everything indirectly rather than directly (Harmer, 2002: 37). They are unconsciously acquiring the language. In relation to the process of learning, Halliwell (1993: 5) believes that children will understand easily through indirect learning because the mind is not engaged on the language.

The third characteristic is that young learners can understand the language not just from explanation, but also from what they see and listen, and when they can touch or interact with (Harmer, 2002: 37). Furthismore, they like to talk. Halliwell (1993: 7) support this by saying that young learners need to talk with the othis, for example they can do pair work and discussion. In addition, Bruner in Cameron (2001: 8) said that talk can support a child in carrying out an activity, as a kind of verbal version of the fine-tuned help. However, the teacher should adjust the talk to the students' level (Abe, 1991).

In relation to talk, Williams proposes a kind of a collaborative conversation.Wells in Williams (mel.williams@paston.co.uk) believes that collaborative conversation can help children to shape and arrive 
at shared meanings and understandings. Fihis (in mel.williams@paston.co.uk) also comments the importance of conversation in the development of thinking, appearing to echo Vygotsky's view that the process of transferring ideas into language plays an important part in stimulating overall development. All learners need to be working with ideas and opinions not merely facts, for the talk to be meaningful and motivating.

The fourth characteristic is that children are more accepting and tending not to analyze; children's ability to mimic is extremely good (Abe, 1991). Thisefore, it is important for the teacher to use learning media. The fifth characteristic is related to the children's curiosity. They are very curious about many things around them (Harmer, 2002: 38). They have high enthusiasm with many things (mel.williams@paston.co.uk). Thisefore, the teacher can motivate the students easily.

Next, the children like to ask for teacher's attention and have approval from him/his (Harmer, 2002: 38). Meanwhile, praise can be given whise and when it is due and discipline is form, consistent, and fair (mel.williams@paston.co.uk).

Seventh, young learners like to talk about themselves, and respond well to learning that uses themselves and their own lives as main topics in the classroom (Harmer, 2002: 38). Eighth, children have a limited attention span; unless activities are extremely engaging they can easily get bored, losing interest after ten minutes or so (Harmer, 2002: 38). Similarly Cameron (2001: 15) comments that children are more easily diverted and distracted by othis learners. In relation to the students' interest, Halliwell believes that children have 
instinct for play and fun (Halliwell, 1993: 6). Thisefore, they should have enormous activities with games and moving around. Ninth, children are creative with grammatical forms and concepts (Halliwell, 1993: 4). They will try to communicate by actively recombining and constructing sentences. They understand the concepts by giving reasons after producing sentences.

Finally, children have imaginative thinking. They test out their versions of the world through fantasy and confirm how the world actually is by imagining now it might be happened (Halliwell, 1993: 7).

a. Theories of Teaching English to Young Learners

Learning and teaching are related each other. The processes of teaching are all efforts to construct opportunities for learning and to help learners take advantage of learning (Cameron, 2001: 242). Brown (2000: 7) said that teaching is showing or helping someone to learn how to do something, giving instructions, guiding in the study of something, providing with knowledge, causing to know or understand.

In addition, Brown (2000: 7) states that teaching cannot be defined apart from learning. Teaching is guiding and facilitating learning, enabling the learner to learn, setting that condition for learning. In the othis hand, teaching is the process to make someone know and understand about something. Brown (2000: 8) also said that an extended definition of teaching will produce governing principles for choosing certain methods and techniques. 
In the teaching and learning process, each child can learn better than othiss in different ways. They have their own profile of meta-cognitive ability. In relation to meta-cognitive ability, Gardner (2003) proposes nine multiple intelligences which include linguistic, logical-mathematical, spatial, musical, bodilykinesthetic, interpersonal, intrapersonal, naturalist and existential.

Naturally, young learners still depend on the teacher in the classroom. The teacher's role is a source of guidance and help. However, if learners become active participants, they need to be independent and autonomous in doing the tasks (mel.williams@paston.co.uk). So, it is possible for the teacher to develop pair and group works in the classroom. Students can develop their own ability by themselves.

Cameron (2001: 20) said that children learn in social context. Learning to do things and learning to think are both helped by interacting with an adult. It is strengthened by Bruner that interaction between children and adults can help them to solve problems in learning (Cameron, 2001: 8). Similarly, Piaget in Abe (1991) also said that active interaction of the learner with the physical and social environment is also significant factors especially between student-student and also student-teacher.

Furthismore, Hudelson (1991) comments that language acquisition occurs through social interaction and through having to use the language with othiss in authentic communication settings. He adds that Acquisition occurs through learners conclude how the language works. So, learner needs opportunities 
to use and to experiment with the new language through talk with each othis and will get language input from othiss.

Adult can help children in communication. Cameron (2001: 19) said that children will try to find and construct meaning and purpose for what adults say to them and ask them to do. They can guess the meaning from their background knowledge which is limited and partial.

Meanwhile, Zone of Proximal Development of Vygotsky (1990) also explains that children to learn in social context. Cameron (2001: 20) supports this by saying that in both language and cognitive development, the ZPD or immediate potential of the child is of central importance for effective learning. Thisefore, he describes that routines and scaffolding are two types of language-using strategies that seem to be especially helpful in making space for children's growth. New language need to be used by student-student or student-teacher. In addition, Krahen (1982) said that using English should be related directly to activities in which children are engaged.

Children's foreign language learning depends on what they experience (Cameron, 2001: 20). He adds that activities in the classrooms will create a kind of 'environment' for learning. It is supported by Hudelson (1991) who said that children generally learn by doing. They need to engage with language in every activity and task; they need to be working on meaningful tasks and use language to accomplish those tasks. Thisefore, teachers can develop tasks and activities based on familiarity of topics into learning experiences. In addition, the teacher should prepare the 
tasks and activities based on the learner's perspective (mel.williams@paston.co.uk). Sometimes however, the teacher needs to simplify the tasks by breaking it down into smaller steps.

\section{The Meaning of Writing}

As one of the four language skills, writing has always occupied a place in most English language course. One of the reasons is that more and more people need to learn to write in English for occupational or academic purpose. Thus, in term of students needs, writing occupies an equal role with the othis language skills (Endang Fauziati, 2008: 141). We need to learn writing to support the othis language skills. By learning to write, we develop our vocabulary while learning grammar correctly.

Murcia (2001: 207) states that writing as a communicative activity needs to be encouraged and nurtured during the language learners' course of study. The psycholinguist Eric Lenneberg (1997) in Brown (2001: 334) said that writing islike swimming. It relates to the discussion of "species of specific" human behaviour, that human being universally learn to walk and to talk, but that swimming and writing are culturally specific; they both are learned behaviors. The process of writing needs an interaction between the writer and the reader via text. So, the writer must try to write a clear, relevant, truthful, informative, interesting, and memorable text.

In the early stage, reading and writing can be learned at a similar pace, usually in reading slightly ahead of writing. If the children are writing ability falls too far behind, we may need to spend extra time on giving writing exercise. However, if we need to do this, 
it is much better to integrate longer writing sessions into almost all of our lessons, rathis than have special lessons for writing and then stop writing for a while. The children need to practice writing regularly in order to make good progress.

When helping the students to become better writer, teacher has a number of crucial tasks to perform. This is true when the students are doing writing activities. The teacher has to perform before, during and after students writing (Jeremy Harmer, 2004: 41-42) are the following:

\section{Demonstrating}

The students need to be aware of writing conventions and genre constraints in specific types of writing. The teacher has to be able to draw the features to the students' attention.

2. Motivating and provoking

The teacher can help the students into having ideas, entrusting them with the value of the task, and persuading them what fun it can be.

3. Supporting

Teacher needs to be extremely supportive when students are practicing writing in the class, except during the exam. The teacher's role are the motivator and provoker.

4. Responding

In responding, we react to the content and contractions of a piece supportively and make suggestions for its improvement.

5. Evaluating

When we do want to evaluate students' work, telling both them and us how well they have done. 
The process of writing indeed is greatly affected by the content (subject matter) of the writing. The types of writing, they are shopping lists, letter, essaid, reports, or novels. And the medium, it is written in pen and paper, computer word files, live chat, etc. But in all of these cases it is suggested that the process has four main elements (Jeremy Harmer, 2004: 4-5):

1. Planning

The writers plan what they are going to write. Before starting to write, they try and decide what the things they are going to say are. In planning, the writers have to think three main issues. They are the purpose, the audience, and the content structure.

2. Drafting

Draft is refers to the first version of a piece of writing. This first 'Go' towards a text is often done on the assumption that it will be amended later.

3. Editing (reflecting and revising)

The writers may use a different form of words for particular sentence if the writers' way of writing the text is ambiguous or confusing. They may move the paragraph or write new sentence. Reflecting and revising can help the reader to give comment and make suggestions.

4. Forming Final Version

The writers produce their final version when they have edited their draft and make the changes they consider to be necessary.

The most basic form of parallel writing is the kind of sentence writing that is often used for grammar reinforcement. Students are given model sentences and then have to write similar sentence based on 
information given by their teacher. That is given in elementary school. The fifth year students are taught dealing with the material of describing objects. The teacher teaches vocabulary to help the students make sentence in their writing. In the lesson of describing objects, the teacher gives a picture and then the students make simple sentences about the picture.

\section{Teaching and Learning of Writing subjects in Elementary School}

Children in primary or elementary school settings generally learn by doing (Piaget, 1995 in Endang Fauziati, 2008: 164). The children need to be active rathis than passive. They will enjoy their activities and they can catch and understand what they learn as good experiences.

We may give the children a basic a model sentence such as, Fish can swim. The second sentence we give them might be just a prompt such as, ... can .... We can write this prompts on the board or dictate them and have the children fill in the sentence with their own ideas. Then we may give the children a few more samples sentences and reduce the prompts even more, such as, Birds ..., You ..., and My little sister .... Afterwards, the children can write three or five more sentences using the same patterns.

The children can spell the animal or object in a picture, or write something about using the target language or othis patterns learned previously. For example, a picture of a cat could lead to sentences such as, It is a cat. It is a big cat. It is a black and white cat. I think it likes having fun. I think it can climb trees, and, It is bigger than my cat. As a course progresses, the children learn to express themselves more. In a multiple skills course, they will be able to understand, say, read, and 
write these kinds of sentences (David Paul, 2003: 98). Harmer gives examples to children in elementary school in writing write sentences. In this example, students are given information about particular character. They then see how this information can be combined in sentences with and and but. Such as:

He likes pop but he does not like classical music.

He likes football and tennis.

He like watching films and going out to parks.

He likes spicy food but he does not like raw fish.

After the teacher gives examples, then the students write similar sentences saying what music, sport, entertainment, and food they like. They must use and and but. By this example, the students learn to write in making sentences, increase vocabulary and practice to use grammar correctly.

Brown has other ways to teach the children at the beginning level of learning to write, students will simply "write down" English letters, words, and possibly sentences in order to learn the conventions of the orthographic code. Some forms of dictation fall into this category, although dictation can serve to teach and test highis-order processing as well. Dictations typically involve the following steps (Brown, 2000: 343344):

1. Teacher reads a short paragraph once or twice at normal speed.

2. Teacher reads the paragraph in short phrase units of three or each four words, and each unit is followed by a pause.

3. During the pause, students write exactly what they hear.

4. Teacher then reads the whole paragraph once more at normal speed so students can check their writing. 
5. Scoring of students' written work can utilize a number of rubrics for assigning points. Usually spelling and punctuation errors are not considered as serve as grammatical errors.

In this ways, the students must be concentration with their material. So, they can practice their skills in listening, vocabulary, and writing.

The last example is writing games (Silvers, 1988 in Fauziati, 2008: 169-170). It is called jumbled words. The games can be used effectively as eithis individual or team competitions. The students are given a list of words about something, such as fruits, transportation, colors, professions, animals, etc. But the letters in each word are jumbled, so the students must rewrite the jumble word correctly. The winner is students or team with the most correct words within the allotted time. The following examples are jumbled words from the category colour.

1. L-B-E-U : BLUE

2. G-E-E-R-N : GREEN

3. D-R-E :RED

In this activities can give good atmosphise in teaching learning. If the students are difficult to answer, the teacher can give pictures to help the students.

All of the examples above are effectively perform in teaching writing subjects in elementary school. The students can begin to write, it will be easier for them to write in making paragraph in junior or senior high school. 
Contextual Teaching and Learning (CTL)

Brain works to look for meaning. When brain gets the meaning, it learns and remembers. So, brain works appropriately along with one's experience. The ability of brain is to find the meaning, which motivated the students to join their assignments with their daily life or their experiences. So, the students can remember what they learn. This is appropriate with the aim of Contextual Teaching and Learning.

Contextual Teaching and Learning (CTL) helps us relate subject matter content to real world situations and motivate students to make connections between knowledge and its applications to their lives as family members, citizens, and workers and engage in the hard work that learning requires. Contextual teaching and learning strategies (http://www.cew.wisc.edu/teachnet/ctl/):

1. Problem based

Contextual Teaching and Learning can be started with a simulated or real problem. Students use critical thinking skills and draw upon multiple content areas to solve the problems. Worthwhile problems that are relevant to students' families, school experiences, workplaces, and communities hold greater personal meaning for students.

2. Using multiple context

Contextual Teaching Learning experiences are enriched when students learn skills in multiple contexts (i.e. school, community, workplace, family).

3. Drawing upon student diversity

On the whole, our student population is becoming more diverse, and with increased diversity comes differences in values, social mores, 
and perspectives. Team collaboration and group learning activities respect students' diverse histories, broaden perspectives, and build inter-personal skill.

4. Supporting self-regulated learning

Students must become more aware how they process information, employ problem-solving strategies, and use background knowledge. CTL experiences should allow for trial and error; provide time and structure for reflection; and provide adequate support to assist students to move from dependent to independent learning.

5. Using interdependent learning groups

Learning groups, or learning communities, are establihed in workplaces and schools in an effort to share knowledge, focus on goals, and allow all to teach and learn from each othis. When learning communities are establihed in schools, educators act as coaches, facilitators, and mentors.

6. Employing authentic assessment

Authentic assessment is used to monitor student progress and inform teaching practices.

According to contextual learning theory, learning occurs only when students process new information or knowledge in such a way that it makes sense to them in their own frames of reference (their own inner worlds of memory, experience, and response). Contextual Teaching and Learning theory be success because this system asks the students to act naturally. According to Alwasilah in Johnson (2009: 65-66), to achieve the aim, the system of Contextual Teaching and Learning has components, they are: 
1. Making meaningful connections

2. Doing significant work

3. Self-regulated learning

4. Collaborating

5. Critical and creative thinking

6. Nurturing the individual

7. Reaching high standards

8. Using authentic assessment

These are seven components of contextual teaching and learning in http://bandono.web.id.2008/03/07menyusun-model-pembelajarancontextual-teaching-and-learning-ctl.php, these are:

1. Inquiry

Inquiry is cyclical process in arranging knowledge or concept from doing observation, ask, investigation, analysis, and then arranging theory or concept.

2. Questioning

This concept is questioning activities which are done by teacher and students. The questions which are addressed by the teacher are done to give opportunity for students to think critically and creatively. The questions of the students are caused by curiosity.

3. Constructivism

This concept demands the students to arrange the meaning of new experiences which based on certain knowledge.

4. Learning Community

Community or group work who have function as communication to shred out the experience and idea. The students can make little or big group, do with the same level of class, or do with society. 
5. Authentic Assessment

It is a procedure of value to show the ability of the students (knowledge and attitude skill).

6. Reflection

To give response to events, activities, and experiences which have a purpose of identifying in order to conduct of improvement and reaching a state of perfection.

7. Modeling

The students learn or do something appropriate with model which is given by the teacher. The teacher gives model about how to learn. The model can be taken from students, magazine, internet, etc

According to Alwasilah in Johnson (2009: 62) in Contextual Teaching and Learning have 3 natural of principles, they are:

1. Interdependent

This principle asks the teacher to know the connection with othis teacher, students, society, and earth. Interdependent principle supports to cooperation. With cooperation, the students can find the problems, make program, and solve the problem.

2. Differentiation

Differentiation supports the universe to get unlimited of variety. The teacher will teach with creativity, uniqueness, variety, and cooperation.

3. Self Arrangement

This principle asks the teacher to supports every student to develop their ability. Contextual Teaching and Learning helps the students to obtain academic superiority, skill, and develop their character with relate among the assignments, experiences, and knowledge. 
Contextual Teaching and Learning offers new things for innovative teacher. It is refers to the components and principles of Contextual Teaching and Learning. Many teachers say that their children change to move forward rapidly when they connect the lesson with experience or real things. Also, the disobedient and lazy students are more focus to learn and their achievement developed. So, Contextual Teaching and Learning can help the teacher to teach and help the students to catch and understand and understand the material easier. Because, when the students connect the lesson with their experiences, the students find the meaning, and the meaning gives a reason to learn.

\section{Research Method}

The strategy of the research which is used in this study is descriptive qualitative. According to Moleong (2009: 5) qualitative research tells about attitudes, opinions, feels, and behavior of individual or group. The data of qualitative research gets from interview. Bogdan and Taylor in Moleong (2009: 4) states that qualitative research as research procedure who is get descriptive data of word from someone in oral or written. This research needs someone to get the data. The research is done by interview or observation.

In this research, the writer took the students in second year of SDN 3 Bareng Lor Klaten and English teacher as the subject of the study. They are 30 students, 13 are male students (boys) and 17 are female students (girls). The English teacher is Mr Samingan S.Pd He taught in SDN 3 Bareng Lor Klaten as English teacher during thirteen years.

\section{Finding}


In collecting the data, the writer used observation, interview, and the documentation. The data were classified based on the matters discussed in this study of contextual teaching and learning in teaching and learning writing to the second class students of SDN 3 Bareng Lor Klaten as follows:

1. Preparation

The writer analyzed lesson plans gained from the teacher after the interview was done. The preparations were includes competence standard, basic competence, indicator, the objective of teaching activity and the material, etc. The furthis explanations are as follows:

a. Standard Competence

The standard competence in the lesson plan was "colour".

b. Basic Competence

Basic competence must be explained clearly. Basic competence will be orientation by the teacher to establish the material. The basic competence in the lesson plan was "colour".

c. Indicator

Indicator spells out about basic competence. The teacher writes the indicator on his lesson plan about colour.

d. The purposes of the Teaching and Learning

1. To write colour correctly

2. To mention colour with pronunciation correctly

3. To answer the questions with pronunciation correctly 


\section{e. Material}

The material of colour: Red, yellow, Green, Blue, White, Black, Brown

f. Teaching and Learning Activity

The teaching and learning activities are about:

1. Opening

a. The students make questions and answer about information which is got from the teacher.

b. The students understand the aims of the teaching and learning.

2. Main Activity

a. Exploration

1) The students pay attention to the explanation of the teacher.

2) The students write the main of explanation of the teacher.

3) The students hear and do the instruction of the teacher.

b. Elaboration

1) The students see and try to do the explanation of the teacher.

2) The students practice to give question to othis students.

3) Othis students answer the question to use expression of pronunciation correctly.

4) The students practice in group. 
c. Confirmation

1) The teacher gives motivation to students in writing about the assignment.

2) The teacher gives reflection of the result of the study.

3. Closing

a. The students tell about the problems of the study.

b. The students connect between the material and the daily life.

c. Teaching and Learning Method

Teaching and Learning Method is a way to deliver the material from the teacher to students. The teaching and learning process used contextual teaching and learning method. The teacher made talkative, question answer, discussion, giving evaluation, and presentation.

d. Media

Media is real thing that help the teacher to deliver the information from source of message to the receiver. In this study, the source of message or information was the teacher and the receiver was the students. This lesson plan told that the teaching and learning process uses colourful ballons as a media.

The source of teaching and learning is something that can be used to get information. The examples of the source of teaching and learning are lecturer, teacher, text book, internet, etc. In this lesson plan told that the teaching and learning 
process used pictures with colour and short video about colour.

e. Time Allocation

Time allocation is sum of the time which is needed of the teacher to deliver the material. By the lesson plan, we knew that the teacher needed $2 \times 35$ minutes.

Related with preparation above, the writer triangulates it by having a document and interview. It can be seen in (appendix), and (appendix) as follows:

According to the document and interview above, the teacher made a lesson plan before teaching and learning process. The teacher claimed that he made the lesson plan appropriate with EEC (Exploration, Elaboration and Confirmation). The lesson plan consists of the identity of the school, the name of the school, the semester, competence standard, indicator, basic competence, the time allocation, teaching and learning activity (opening, main activity, and closing), the method, the source of learning, and evaluation. The lesson plan was signed by the English teacher and approved by the headmaster of SDN 3 Bareng Lor Klaten. It was written in Indonesian language.

2. The Contextual Teaching and Learning Process of Teaching and Learning Writing

Based on the writer's observation, the writer can report the information related to the process of contextual teaching and learning in teaching and learning writing to the second class at SDN 3 Bareng Lor Klaten. The observation was carried out during the teaching and learning process. Observation did for 
twice in different material. These were two topics in this observation. First, it was concluded in on 8 January, 2014. In this activity had part of body as the topic and the last it was held on January 15, 2014. The topic of this activity was about daily activities. The teaching and learning process, it was concluded in $2 \times 35$ minutes each day. From this observation the writer got the information about the process of contextual teaching and learning in teaching and learning writing.

a. Opening

The situation of the classroom when contextual teaching and learning in teaching and learning writing held is: first, when the teacher came to the classroom, the students were busy in their activities. Then, the teacher greeted:

Teacher : Good morning, how are you today?

Students : Good morning, I am fine. Thank, and you?

Teacher : I am fine too. Did you ever see rainbow?

Students : Yes

Teacher : Do you know what colour is rainbow? Mention it.

Students : Yes. It is red, yellow, green

Related with apperception above, this activity is triangulated by having an observation. According to the observation above, the teacher's activities were started by greeting the class. The teacher's purpose by greeting the class is to create English atmosphise in the class.

b. The Main Activity

The main activity in this study consists of two activities, they are as follows:

1) Teacher's Activities 
a) The teacher asked the students to collect their assignment, which was colourful ballon with the name. Then the teacher asked a student to come in front of the class. Teacher point toward the ballon and ask what colour is it? Then the students answered the name of its. Based on the interview, the writer triangulates the observation data below:

The writer : Did you use media to teach your students?

The teacher : Yes, I used pictures.

Based on the data above, the teacher used picture in teaching and learning to create motivation of students.

b) Then, Mr. Samingan asked his students to prepare a paper. He took one by one the colourful ballon and the students wrote the colour of the ballon in English.

The writer : According to you, what do colourful ballon influence the motivation of your students?

The teacher : Yes.

According to the observation and interview above, the teacher used colourful ballon in teaching and learning to create motivation of students.

c) Then the teacher was random the characters of word and the students arranged into true word. It is called jumbled words.

1. $\mathrm{g}-\mathrm{e}-\mathrm{r}-\mathrm{e}-\mathrm{n} \quad$ : green

2. b-c-l-a-k : black

3. e-w-i-h-t : white

4. r-d-e : red 
5. e-b-l-u : blue

The students could answer the questions correctly. After that, the teacher asked students to stand up in face to face. They sang a song about rainbow and this song was suitable with the material of colour .The situation was very crowded.

From the observation above, the teacher was successful to create the nice learning atmosphere in the class.

2) Students' Activities

a) The students collected their assignments .Those were colourful ballons. Based on the interview the writer triangulates the observation data below:

The writer : I saw that you collected colourful ballons. Did you feel it is difficult to do it?

The students : No, we did not.

According to the observation and interview above, the students studied about colouful ballon. They claimed that they did not get difficulty to do the assignments.

b) The students came in the front of the class. Based on the interview, the writer triangulates the observation data below:

The writer : Mr. Sam asked you to come in front of the class, what did you do?

The student : Mr.Sam asked me to point to the colourful ballon and answered the questions in the white board. 
According to the observation and interview above, the teaching and learning process used student as media of teaching and learning. It was done to help the students catch and understand and understand the material well.

c) The students prepared a paper. They answered the questions from the teacher. The result was good.

d) The students to stand up in face to face. They sang a song about rainbow

The writer : I saw that Mrs. Sam asked all of you stand up and then touch the colourful ballon and sing to get this. How about this teaching and learning process? Did you feel happy or get bored?

The students : We did not feel bored. We feel happy.

According to the observation and interview above, the teacher used singing a song to create the atmosphise in the class. That was successful, the students felt happy.

\section{c. Closing Activity}

Closing activity was an activity to close the teaching activity. Closing activity which was done by the teacher in this study is: the teacher gave opportunity for the students to ask about the material if they were not clear, but no questions addressed to him. Then the teacher gave homework to the students. After that, the students get ready to go home. The leader of the class led the the students to pray. After finishing it, all of students performed handshaking to the teacher. Based on the observation above, the teacher closed the lesson and 
gave opportunity to the students to ask and he gave homework to the students.

\section{The Methods}

Methods are sets of procedures that are considered as the means or the way in which a specific instructional activity is done, such as contextual teaching and learning.

a. The teacher asked students to collect their homework. They were the colorful ballon students to tell the name of the picture about the part of the body.

b. The teacher asked a student to come in front of the class, he was Ani. Then the teacher asks to Ani to point to the whiteboard and asked the students to tell the colour.

c. After that, the teacher asked students to stand up in face to face. They sang a song about rainbow.

Based on observation above, the teacher used colourful ballon, and sang a song in teaching and learning process.

Media helps the teacher to deliver material. Using media in teaching and learning is appropriate with contextual teaching and earning method.

\section{Evaluation of Teaching Activity}

Evaluation was very important to measure the students' understanding about the material of teaching activity. The data about the evaluation of teaching activity in this study are as follows: the teacher gave ten questions.

Based on the observation above, in this teaching and learning process, the teacher gave an evaluation by asking ten questions spontaneously and then the students answered it in a 
written form. Based on the observation above, in this teaching and learning process, the teacher gave an evaluation by asking five questions spontaneously and then the students answered it orally.

5. The Material

The data concerning with the material in this study as follows: the teacher ask the students to bring colourful ballon. And then, the writer asked to the students "What is the theme your English lesson today?". The students answered "the colour". Then, the writer asked "Mr Sam asked you to come in front of the class, what did you do?", and the student answered "Mr. Sam asked me to point to colour of the picture and answered the questions in the whiteboard".

From observation the writer can conclude:

a) The role of the teacher is important in teaching and learning process. The teacher must be active to make the students interested and understand the subject. He tries to make the lesson easy by using pictures, experiences or the othis thing. It can help the students understand the subject easily and memorize the material. From explanation above can be seen that the teacher is subject of the study. The role of the teacher as motivator, and facilitator. Motivator means that the teacher can motivate their students to improve their skills especially in learning writing. Facilitator means that the teacher be a ceaseless facilitator to the students.

b) The instructional material is interest. It can give enthusiasm for the students to enjoy in the class. So, the role of the 
instructional material is important in teaching and learning successfully.

c) All of the students are active and enthusiasm in teaching and learning process. The students always pay attention to their teacher. Most of them understand the subject because of follow the teaching and learning well. When the teacher asks them to answer the questions or come in front of the class, they are not afraid. They can answer the questions correctly. The students as the object of the study. The role of the students is important in teaching and learning. The students are one of important elements in teaching and learning successfully.

d) Media is one of the teaching aids. It is suitable with the contextual teaching and learning method. One of the important elements in teaching and learning successfully is by using good teaching aids. From the explanation above, it can be seen that by using media (for example colourful ballon) can make the students more active and catch and understand the material well.

\section{Conclusion}

From the data, the writer can find that with CTL the students got more interest in the teaching and learning process and did not easily get bored. The classroom situation also becomes alive. The students are attention the teacher and do what the teacher said.

Based on this research, the writer would like to give the suggestion. For the students to continuously practice English at school 
and at home, become more active and regular in learning English ask to their teacher if they have difficulties, it is is not advised to be ashamed to practice English. The teacher must be able to create classroom situation more interestingly by using this media, give more attention to the students who sit on behind line.

\section{References}

Alwasilah, Chaedar. 2009. Contextual Teaching and Learning. Bandung: MLC.

Arikunto, Suharsimi. 1998. Prosedure Penelitian Suatu Pendekatan Praktek. Jakarta: Bina Aksara.

Brown, Douglas. 2000. Teaching by Principles. New York: Pearson Education.

Brown, Douglas. 2000. Principles of Language Learning and Teaching. New York: Pearson Education.

Bungin, Burhan. 2007. Penelitian Kualitatif. Jakarta: Prenada Media Group

Elaine.2009. Contextual Teaching \& Learning. (Terjemahan). Bandung : Mizan

Fauziati, Endang. 2008. Teaching of English as a Foreign Language (TEFL). Surakarta: Muhammadiyah University Press.

Harmer, Jeremy. 2004. How to Teach Writing. England: Pearson Education.

Hisgenhahn and Matthew. 2008. Theories of Learning. Jakarta: Prenada Media Group.

Hornby, A. S. 1995. Oxford Learner's Pocket Dictionary. New York: Oxford University Press.

http://bandono.web.id.2008/03/07menyusun-model-pembelajarancontextual-teaching-and-learning-ctl.php

http://www.cew.wisc.edu/teachnet/ctl/

Hyland, Ken. 2002. Teaching and Researching Writing. England: Pearson Education.

McCrimmon, James. M. 1984. Writing with a Purpose. USA: Houghton Mifflin Company. 
Miles, M. B and Huberman, A. M. 2009. Analisis Data Kualitatif. Jakarta: Penerbit Universitas Indonesia.

Moleong, Lexy J. 1989. Metodologi Penelitian Kuliatitatif. Bandung: Remadja Rosdakarya.

Murcia, Celce Marianne. 2001. Teaching English as a Second or Foreign Language. USA: Heinle \& Heinle.

Paul, David. 2003. Teaching English to Children in Asia. Hong Kong: Pearson Education.

Rahma, Arika. 2009. Teaching Vocabulary by Using Picture ( A Case Study of The first year Students of SDIT An Najjah Jatinom Klaten in 2009). Unpublihed: Widya Dharma University.

Seliger, Hisbert. W and Elana Shohamy. 1989. Second Language Research Methods. New York: Oxford University Press.

Sharma, Kadambari and Tripat Tuteja. 2005. Principles and Practices of Language Teaching. Delhi: Roshan Offset Printers.

Sutopo, H. B. 2006. Metodologi Penelitian Kualitatif I. Surakarta: Sebelas Maret University Press.

Yin, Robert. 1996. Studi Kasus Desain dan Metode. Jakarta: Raja Grafindo Persada. 